\title{
Sam Shepard'ın Gömülü Çocuk Adlı Oyununda Uzam ve Zaman Space and Time in Sam Shepard's Buried Child
}

\section{Levent Suner ${ }^{*}$}

\section{Özet}

Sam Shepard Gömülü Çocuk adlı oyununda geçmişin izlerinden asla kurtulunamadığı izleğini işler.Geçmiş gelecekte bir lanet gibi yaşayacak ve aile üyelerini tutsak edecektir. İzlek, uzam ve zaman kullanımı ile pekiş̧irilmekte, görsel göstergelerle desteklenmektedir.

\begin{abstract}
Sam Shepard in Buried Child deals with the theme of the impossibility of getting rid of the traces of the past. The past will live in the future as a curse and imprison the family members. The theme is strengthened by the use of space and time, and supported by visual signs.
\end{abstract}

İlk kez 27 Haziran 1978'de, San Francisco'da, Magic Theatre'da Robert Wooddruff'un rejisi ile sahnelenen, 1979'da Pulitzer Ödülü'nü kazanarak tanınan Gömülü Çocuk (Buried Child) Sam Shepard'ın aile oyunu üçlemesinin* ikinci oyunudur. Oyun üç perdedir ve üç perde de aynı uzamda geçer. Shepard mekanı aşă̆ıda alıntılandı̆̆ı gibi betimler.

Sahnenin sol tarafında, basamaklarına soluk yıpranmış bir halı serili olan eski tahta bir merdiven. Basamaklar yukarıdaki çıkıntıda son bulur, üst kat görünmez. Sağ tarafta eski, koyu yeşil bir kanepe durur. Kanepenin sağ tarafında sarı gölgeli 1 şı veren bir lamba ve üzerinde küçük ilaç şişeleri olan bir sehpa vardır. Kanepenin karşısında ekranı kanepeye dönük olan eski model kahverengi bir televizyon durur. Ekrandan titrek mavi bir 1şık gelir fakat hiçbir görüntü veya ses yoktur. Lambanın ve televizyonun ışığı karanlık sahneyi aydınlatır. Kanepenin arkasındaki boşlukta bir paravanla ayrılmış büyük, tahta döşemeli bir veranda vardır. Bunun ardında ise karaağaçların gölgesi görünür. ${ }^{1}$

Oyun başladığında yağmur yağmaktadır. Gündüzdür. Dodge kanepede oturmuş televizyon seyretmektedir. Seksen yaşına yakın, çok zayıf ve hasta görünüşlüdür. Televizyon ekranının mavi 1şı̆̆ı yüzüne yansır. Kahverengi bir battaniyeye sıkıca sarılmıştır. Sürekli öksüren Dodge oturduğu kanepenin minderinin altına sakladığı viskisini çıkarır, gizlice içer ve tekrar yerine koyar. Üst kattan karısı Halie’nin sesi duyulur. İlacını içip içmediğini sorar Dodge'a. Sanki aynı evde değil de farklı mekanlarda yaşıyor, farklı mekanlardan konuşuyor gibidirler. Birbirlerini görmeden alt kat (salon) ve üst kat (yatak odası) arasında yapılan uzun konuşma boyunca Dodge ve Halie'nin üç oğlu olduğunu

\footnotetext{
* Yrd.Doç.Dr., Ankara Üniversitesi, D.T.C.Fakültesi, Tiyatro Bölümü, Oyunculuk Anasanat Dalı

* Diğerleri: Aç Sınıfin Laneti (Curse of the Starving Class); Vahşi Batı (True West)

${ }^{1}$ Sam Shepard, Toplu Oyunları 1: Gömülü Çocuk, Çev.: Şükran Yücel; Vahşi Batı, Çev.: Yıldırım Türker; Aç Sınıfin Laneti, Çev.: Pınar Kür (Ankara: Dost Kitabevi Yayınları, 2000), s.39.

Bundan sonra bu metinden yapılacak alıntıların sayfa numarası metin içinde parantez içinde verilecektir.
} 
öğreniriz. En büyükleri Tilden'dir. Elli yaşına yakındır. New Meksiko'da yaşarken başının derde girmesinden dolayı ailesinin yanına dönmüştür. Ortanca oğul Bradley Tilden'dan beş yaş küçüktür. Bacağını elektrikli testereye kaptırmıştır. Takma, tahta bir bacakla yürüyebilmektedir. En küçük oğul Ansel ise ölmüştür. Halie'nin gözünde bir kahraman olarak nitelenen Ansel bir motel odasında ölü bulunmuştur. Halie, Ansel'in bir heykelini yaptırmayı düşünmektedir. Bunun için de Peder Dewis ile konuşmaya gidecektir.

Halie ve Dodge'un konuşma sürerken Tilden, kolları taze mısır koçanlarıyla dolu bir halde solda bulunan mutfak kapısından içeri girer. Arka bahçeden topladığını söyler bu mısırları. Oysa ki, Halie ve Dodge'a göre 1935 yılından beri arka bahçede hiçbir şey yetişmemiştir. Tilden mısır koçanlarını Dodge'un kucağına bırakır ve mutfağa gider. Dodge firlatıp atar koçanları. Tilden elinde bir süt sağma taburesi ve kovayla geri gelir. Kanepenin yanına koyduğu tabureye oturur. Mısırları tek tek alıp kabuklarını birer birer sıyırarak temizler. Koçanları kovaya koyar, kabukları da ortaya atar. Bu sırada Halie merdivenden aşağı inmektedir, 65 yaşlarındadır. Yas tutuyormuşçasına baştan ayağa siyah giyinmiştir. Elinde siyah bir el çantası başında tüllü bir şapka vardır.

Soyulan mısır kabuklarıla mekan bir çöplüğe dönmüştür. Halie’yi çok sinirlendirir bu durum. Konuşmalar sürerken Dodge arka bahçede gömülü birinden söz eder. Halie öfkeyle susturur Dodge‘u. Konu kapatılır. Halie, Peder Dewis ile görüşmek üzere çıkar. Tilden ve Dodge yalnız kalmıştır. Bir süre sonra Dodge derin bir uykuya dalar. Tilden yerdeki mısır kabuklarını toplar ve uyumakta olan Dodge' un üzerini bu kabuklarla örter. Daha çok kabuk toplar ve her yer temizleninceye kadar bu işlemi tekrarlar. Dodge' un üstü tamamıyla kabuklarla kaplanmıştır. Tilden uyuyan Dodge'a bakar ve sonra çıkar. Bu sırada takma ayağının metal menteşelerinden çıkan gıcırdama sesiyle Bradley gelir dışarıdan. Dodge’u görür. Cebinden çıkardığı elektrikli makası ile uyuyan Dodge’un saçlarını keser. Birinci perde makasın ve yağmurun sesiyle biter.

İkinci perde aynı uzamda geçer. Zaman; gecedir. Yağmur yağmaktadır. Dodge hala uyumaktadır kanepede. Saçı kesilmiştir ve kafatası derisindeki kesikler kanamaktadır. Mısır kabukları, kova ve süt sağma taburesi kalkmış, sahne temizlenmiştir.

Vince ve Shelly verandada görünürler. Vince, Tilden'ın oğludur. 22 yaşındadır. Shelly de Vince'in kız arkadaşıdır. Vince'in elinde bir saksofon kutusu ve bir palto vardır. Altı yıllık bir aradan sonra büyükanne ve büyükbabasının evine dönmüştür. New Meksiko'daki babasını aramaya giderken uğramıştır. Ancak, oyun ilerlediğinde Vince'in temelli kalacağını anlarız. Burada Shepard'ın sık kullandığ1 "eve dönüş" temasını görüyoruz. Vince'in babası Tilden da dönmüştür eve. Eve giren Vince kanepede yatan büyükbabasını fark etmez. Üst kata, büyükannesinin yanına çıkar. Aşağı indiğinde görür büyükbabasını. Ama Dodge tanımamıştır Vince'i. Vince'in bütün çabasına rağmen büyükbaba tanımamakta direnmektedir. Vince babasının New Meksiko'da değil de orada olduğunu öğrenince çok şaşırır. Bu sırada Tilden elinde havuçlarla içeri girer. Dodge gibi Tilden da tanımamışır 
Vince'i, o yokmuş gibi davranmaktadır. Babası Tilden' in New Meksiko'da değil de, o evde uzun süredir yaşadığını öğrenmek Vince'i daha da yaralar. Ne yaparsa yapsın ne babası ne de büyükbabası Vince'i tanımıordur.

Başlangıçta, Shelly büyük bir hayal kırıklığı yaşar. Çünkü bu evde yaşayanlar hayalini kurduğu aile imajına uymamaktadır. İletişimsiz, birbirine yabancı, hastalıklı, acımasız, vahşidir herkes. Ama Shelly gittikçe ortama uyum sağlar. Hatta Tilden ile birlikte arka bahçeden gelen havuçları keser. Vince kendini iyice yalnız hisseder bu durumda. Gittikçe güçsüzleşir. İlişki kurmak imkansızdır. Vince, Dodge’un içki siparişini almak için evden çıkar.

Shelly, Dodge ve Tilden ile yalnız kalır. Tilden Shelly'e bir bebekle ilgili bir öykü anlatır. Dodge'un engellemelerine rağmen Shelly'ye, bir bebeklerinin olduğunu, sonra kaybolduğunu ve kimsenin onu bulamadığını, nerede gömülü olduğunu bilen tek kişinin de Dodge olduğunu söyler. Bu sırada Bradley gelir. İkinci perde Bradley’nin Shelly’ye simgesel taciziyle biter.

Üçüncü perde de aynı uzamda geçer. Zaman; sabah. Yağmur dinmiş, güneş açmıştır. Her yer temizlenmiştir. Havuçlar yoktur. İkinci perde de Tilden'ın getirdiği kova ve tabure kalkmıştır. Vince'in saksofon kutusu ve paltosu hala merdiven dibinde duruyordur. Bradley Dodge'un battaniyesi altında kanepe de uyumakta, Dodge da yerde oturmaktadır. Geceyi dışarıda Peder Dewis ile geçiren Halie de dönmüştür. Dodge birinci ve ikinci perdede saklanan, açıklanmayan sırrı Shelly’ye anlatır : Halie ve Tilden'ın ilişkisinde (ensest bir ilişkiden) bir bebek doğmuştur. Dodge da bu yasak ilişkiden doğan çocuğu öldürmüş ve arka bahçeye gömmüştür. Halie'nin engellemelerine rağmen giz artık ortaya çıkmıştır.

Tüm aile bu suçun utancı altında birleşmiş gibidir. D1ş dünyaya, gerçeğe tamamen kapatmışlardır kendilerini. Kendi yarattıkları dünyanın yanılsamasına öylesine inanmışlardır ki, bu yanılsamayı kıracak, yok edecek dışarıdan gelen hiç kimseye tahammülleri yoktur. Böyle katlanabilmektedirler. Bunu için Vince'i tanımazlar. Oysa "dışarıdan” gelen kendilerinden biridir. Bunu algıladıklarında kabul ederler onu. Vince' in ailenin kirli geçmişine sahip çıkmaktan başka yapabileceği bir şey yoktur: Lanetten kurtulmak mümkün değildir çünkü.

Dodge'un anlattığı öykünün sonunda Vince gelir. Sarhoştur. Başka biridir sanki. Elinde bıçakla Shelly’yi ölümle tehdit edecek kadar değişmiştir. Artık o da eve aittir ve onlardan biri olmuştur. Şimdi de Vince kimseyi tanımıyordur.

Vince'in içki almak için dışarı çıkması bir süre sonra bir kaçışa dönüşmüştür. Bu, kendinden, ailesinden kaçıştır. Vince otomobilde giderken ön camda kendi yüzünü görür. Kendine yabancıdır bu yüz, tanıyamaz. Bu yüz birden annesinin yüzüne dönüşür. Annesinin yüzünü hem ölü, hem canlı olarak görür. Annesinin yüzü onun babasının yüzüne, babasının yüzü de büyükbabasının yüzüne dönüşür. Görür ki, hepsinde aynı kemik yapısı, aynı özellikler vardır. Kaçamayacağını anlar ve döner. Nereye giderse gitsin ailesinin laneti peşini bırakmayacaktır. 
Giz ortaya çıkmış, mirasın bırakılacağı, laneti sürdürecek kişi de dönmüştür. Dodge ölebilir artık. Oyunun sonunda Tilden, elinde arka bahçeden çıkardığı çocuğun cesediyle üst kata, Halie' nin yanına çıar. Aile yüzleşmiştir gerçekle. Halie de yüzleşmelidir. Vince oyunun sonunda Dodge'un kanepesindedir artık.

Oyunda uzam, "içerisi”" (iç uzam) ve "dışarısı" (dış uzam) olmak üzere ayrılmıştır. "Dışarısı" oyun boyunca hiç görmediğimiz ama sürekli bahsedilen, arka bahçedir. Arka bahçe de toprağın altı ve toprağın üstü olmak üzere iki ayrı uzama ayrılmıştır. Toprağın altında Dodge tarafından öldürülen çocuğun cesedi yatmaktadır. Bu evde yaşayanlar kendi uzamlarını (yaşam alanlarını) belirlemişlerdir. Tilden'ın uzamı da bu bahçedir (toprağın üstü). Tilden bütün gününü bu bahçede geçirmekte ve burada yetişen sebzeleri (havuç, mısır) eve taşımaktadır. Oysa ki, Halie ve Dodge' a göre bu bahçede yıllardır hiçbir ürün yetişmemiştir.

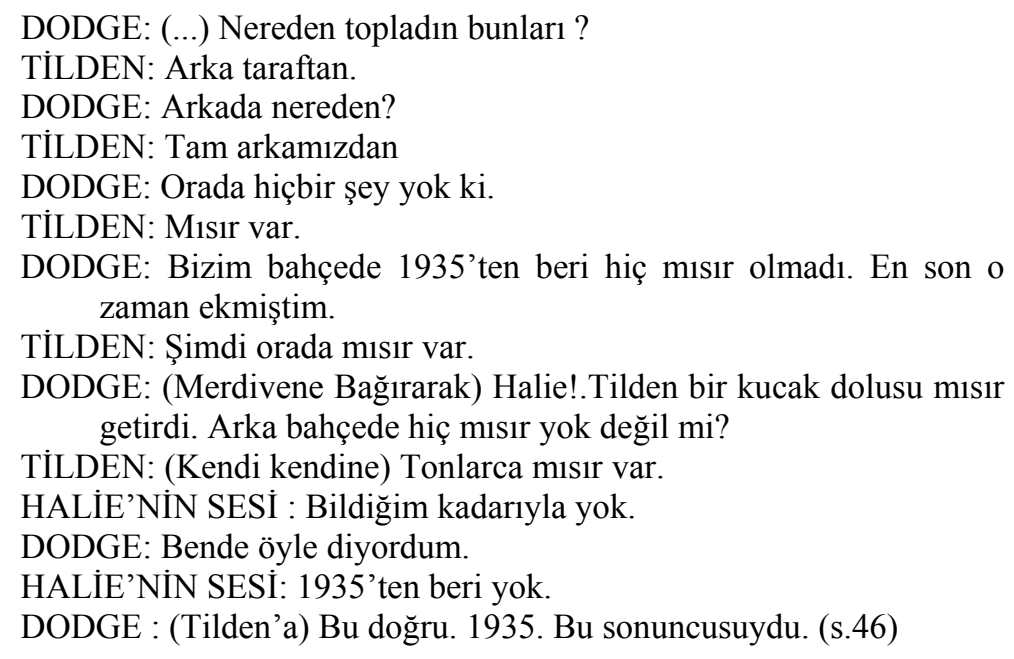

1935, açıkça söylenmese de çocuğun öldürüldüğü yıldır. Bu tarihten sonra aile "gerçekle" olan tüm bağını koparmış, kendi yarattıkları dünyanın yanılsamasına inanmış, bunun dışındaki her şeyi reddetmiştir. Ev, Bachelard'ın söylediği gibi geçmişin gölgelerine duvar örmüş içine de tir tir titreyenleri koymuştur. ${ }^{1}$

Halie ve Dodge için, arka bahçede yetişen ürünleri kabul etmek demek, bu toprağın altında yatan cesedi de kabul etmek demektir. Bu sebzeler topraktan beslenmektedir, aynı zamanda toprağın altında yatan cesetten. Suç o kadar büyüktür ki, toprak da "tonlarca" ürün vermektedir. (Suçun büyüklüğü ile ürünün çokluğu arasında koşutluk vardır.). Bu ürünler (mısır, havuç) onlara arka bahçede yatan "gömülü çocuk"u hatırlatmaktadır. Onlar bu büyük gizle yüzleşme cesaretini gösterecek kadar güçlü değillerdir. Ancak, anılar, yine Bachelard'ın belirttiği gibi “yerleştiği” yere "sağlamca" tutunur. ${ }^{2}$ Gün gelecek, gerçek ortaya çıkacaktır. Evin duvarları tehdidin/tehlikenin (geçmişin/anıların/günahın) içeriye girmesini engelleyemeyecektir.

\footnotetext{
${ }_{1}^{1}$ Gaston Bachelard, Mekanın Poetikası, Çev.: Aykut Derman (İstanbul: Kesit Yayıncıllk, 1996), s.32.

${ }^{2}$ Ayn1, s.37.
} 
Ceset topraktan çıktıktan sonra, gerçekle yüzleşilir; giz kaybolur, yanılsama bozulur. Halie ancak o zaman görmeye başlar bahçedeki sebzeleri:

HALIE : Dodge? Dodge sen misin? Biliyor musun, Tilden mısır
konusunda haklıymış. Şimdiye kadar böyle mısır görmedim. Son
zamanlarda hiç oraya baktın mı? Şimdiden adam boyunda. Hem
de bu zamanda. Havuçlarda var. Patatesler, bezelyeler. Burası
cennet gibi olmuş Dodge. Görsen bir mucize bu. Hiç böylesini
görmemiştim. Belki de yağmurdan oldu. Evet yağmur olmalı...
Dolu dolu sağanak yağmur. Her şeyin köklerine iner. Bir şeyi
büyümeye zorlayamazsın. İçine giremezsin. Her şey toprak
altında saklidır. Görünmez. Topraktan fişkırıncaya kadar
beklemek zorundasın. Küçük, minik filizler. Küçük, minik beyaz
filizler, tüylü ve kırılgandır. Yine de güçlü. Bu bir mucize
Dodge. Bütün hayatımda böyle bir ürün görmedim. Belki de
güneş, evet öyle olmalı. Güneş. (s.109)

Eve (dış uzamdan iç uzama), bahçeden sürekli olarak mısır, havuç gelmesi, günahın o evde hep var olacağını, bundan uzaklaşamayacaklarını, kaçamayacaklarını anlatır. Yağmur yağdıkça cesedin gömülü olduğu toprak ürün verecek, ürün de eve taşınacaktır. Günahtan, gizden kaçış imkansizdır.

Dışarısı hep yağmurludur. Durmamacasına yağan yağmur arka bahçeyi balçık, çamur haline getirmektedir. Tilden bu çamurlara basarak toplamaktadır sebzeleri. Her dışarıdan içeri dönüşünde bu çamurları eve taşımaktadır. Dolayısıyla dış uzam, ürünler ve çamur yoluyla hep içeri taşınmaktadır. Çamur ayrıca, bir durumdan diğerine geçişin; her türlü maddenin ortaya çıkışının; biyolojik işlem ve süreçlerin de sembolüdür. ${ }^{1}$

Dışarının sürekli yağmurlu, kapalı ve puslu olması içerde yaşanan gizle örtüşmektedir. Yağmur yalnızca bu kasabada yağmaktadır. Şöyle der Dodge:

\section{Dodge :Kaliforniya'da, Florida da ya da yarış pistinde yağmur yağmıyor.Sadece Illinois'de yağıyor. Yağmurun yağdığı tek yer burası. Geriye kalan bütün dünya, parlak güneş 1şıkları içinde. (s.52)}

Yağmur/su ölümün olduğu kadar yaşamın da simgesidir; tabii arınmanın da. Shepard, yağmur göstergesi ile hem dışarının içeriye sımasını, hem toprağın incelip, içinde sakladığını ortaya çıkarmasını, hem de su ile günahkarların arınma şansına da sahip olduklarını imlemektedir. Yeter ki günahlarını inkar etmesinler. ${ }^{2}$

Tilden'ın havuç ve mısırları temizlerken kullandığı kova ve süt sağma taburesi de dış uzamın (dışarının) iç uzama (içeriye) sızdığını gösteren nesneler olarak kullanılmaktadır. Her perde değişiminde ortadan kaldırılsa da dışarıya ait bu iki nesne, sonra yeniden Tilden tarafindan getirilmektedir.

\footnotetext{
${ }^{1}$ J.E.Cirlot, "Mud", A Dıctıonary of Symbols.(London: Routledge \& Kegan Paul, 1983), s.222.

2 "Rain", Ayn1, s.271,272.
} 
Dış uzam iç uzamdan, dışarıdan gelenleri önceden görebileceğimiz büyüklükte pencerelerle ve camlı kapıyla ayrılmıştır. Karaağaçların gölgesi de vurmaktadır bu camlı bölmenin ardına. Tekin değildir dışarısı. Bu bağlamda dışarının gizi, karanlığı, içeriden de hissedilmektedir. Cirlot da benzer bir biçimde pencere ve kapının, duvarın aksine dışarıya açıklığı simgelediğini yazar. ${ }^{1}$ Üstelik de, açılan ve kapanan kapılar Bachelard'ın saptadığı gibi “yaşamın tüm öyküsü”nü barındırır. Karaağaçların varlığı da kötülüğü, gizi, karanlığı güçlendirmektedir. "Karaağaçlar", Amerikan tiyatrosundan bir başka oyunu anıştırmaktadır: Karaağaçlar Altında (Tutku) (Desire Under the Elms). Eugene O'Neil'in söz konusu oyunu da bir tür ensest ilişkiye odaklanmıştır. Bottoms anılan benzerliği, Shepard'ın Amerikan tiyatrosundan bazı yazarlara göndermelerde bulunduğu biçiminde yorumlamaktadır. Verdiği örnekler arasında O’ Neill ve sözü edilen oyunu da bulunmaktadır. ${ }^{3}$

Dışarıyı içeriden ayıran canlı bölmenin ardında “Araf” olarak niteleyebileceğimiz bir veranda vardır. Vince ve Shelly’i ilk kez biz bu verandada görürüz. Sanki günahın işlendiği "içerisi” ve çocuğun gömüldüğg̈ "dışarısı”"nın tam ortasında duruyorlardır :Dışarıda kalmak ya da içeride olmak... Vince'e göre buradan bakıldığında her şey doğal, tipik bir ailenin, "tipik Amerikan evi” gibi görünüyordur.

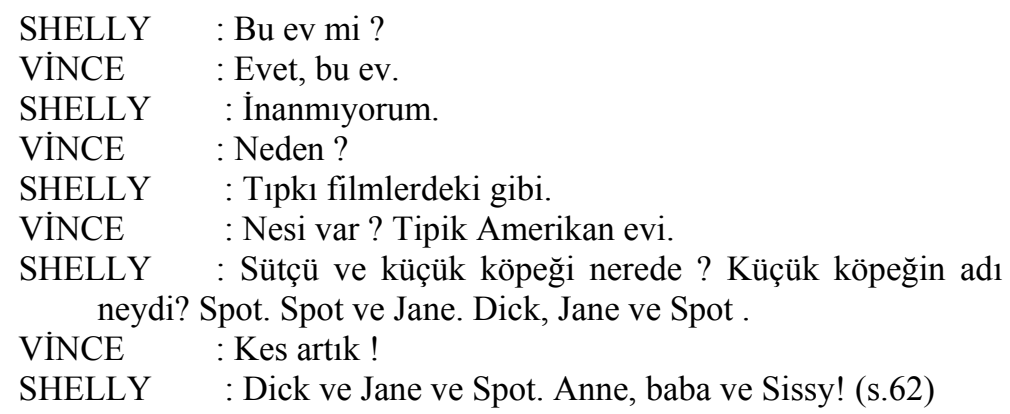

Vince burada, içeride kendini bekleyen lanetten habersiz durmaktadır. İçeri girecektir Vince; atalarının hayaletinden, soyundan kurtulması mümkün değildir çünkü. Kapı açılacak, içeri girecek ve mirasını devralacaktır. Soyunun laneti çekmiştir onu buraya. Bottoms'a göre felaket yazgıdır, insanın genlerinde yazılıdır. ${ }^{4}$

İçerisi (iç uzam) alt kat ve üst kat olmak üzere ayrılmıştır. Herkesin uzamı belirlidir. Alt kat Dodge'un, üst kat (yatak odası) Halie'nin uzamıdır. Bachelard'ın ev tanımı gibi, Halie ve Dodge'un evi de dikey çifte kutupludur. ${ }^{5}$ Aradaki merdiven onları birbirine bağlar. Ancak, bellidir ki, Dodge hiç

\footnotetext{
1 "Door",'Window"; Ayn1, s.85,373.

${ }^{2}$ Bachelard, Mekanin Poetikası, s.257.

${ }^{3}$ Stephen J. Bottoms, "Strychnine in the Gut; Curse of the Starving Class (1977) and Buried Child; The Theatre of Sam Shepard; States of Crisis (New York: Cambridge University Press, 1998), s.159.

${ }^{4}$ Ayn1, s.181.

${ }^{5}$ Ön.ver. s.47.
} 
yukarı çıkmamakta, Halie'nin de aşağıya inme nedeni asla Dodge ile sohbet etmek olmamaktadır. Herkes kendi yaşam alanını belirlemiştir. Diğer bir deyişle, yine Bachelard'ın dediği gibi, "Kovuğuna çekilen bir hayvan gibi içine girmek" istedikleri "köşe"leri belirlemişlerdir. ${ }^{1}$ Köşeleri, onlar için Bachelard'ın sözleriyle: "kozmosa karşı koymak için araçtır". ${ }^{2}$

Sınırlarını ve kabuklarını sertleştiren bireyler, sanki aldıkları mirası bir sonraki nesle devretmek için vardır sadece. Görünmez bu tek amaç için "yaşadıkları”nı sanırken, sezgisel olarak bir kök ve yön bulma telaşıyla çırpınırlar; bu uğurda bilinçli hiçbir eylem yapmadan. Kapatmışlardır kendilerini bu dar uzamlara. Günahın Halie, Tilden ve Dodge üçgeni arasında işlendiğini düşünürsek, uzamın dışına çıkan tek kişi Halie'dir. Halie küçük oğlu Ansel'in heykelinin yapım işini konuşmak için dışarı, Peder Dewis'le görüşmeye gider ve geceyi dışarıda geçirir. Geldiğinde sabah olmuştur. Oysa Tilden ve Dodge kendi uzamlarından ayrılmazlar. Tilden hep arka bahçededir; içeri girdiği zaman da bahçeye ait olan süt sağma taburesi üzerindedir; Dodge ise kanepede. Shepard oyunlarında kadınlar erkeklere göre daha özgürdür ve bulundukları yerden gidebilirler. Halie de evin dışına çıkabilmektedir. İhanetlerine devam eden Halie'nin Peder Dewis ile ilişkisi vardır ve geceyi dışarıda geçirmiştir. Shelly de yaşadığı yerden ayrılmış, Vince ile birlikte gelmiştir.

Dodge'u oyun boyunca, eski ve koyu yeşil renkli bu kanepe üzerinde görürüz. Kendi yalnızlığı ve yabancılaşmışlığını, omuzlarına aldığı ağır günahıyla, tek başına bu kanepede yaşar. Dodge’un içine gömüldüğü bu kanepe, işlediği günahın bedelini ödercesine onun mezarı haline gelmiştir. Kahverengi bir battaniye ile sıkı sıkıya örtmüştür kendini. Kahverengi rengiyle bu battaniye toprağı imlemektedir. Birinci perdede Tilden'ın kanepede uyuyan Dodge'u mısır kabuklarıyla örtmesi battaniyeyi toprak, kanepeyi de mezar olarak algılamamızı güçlendirir. Dodge, çocuğu arka bahçede, toprağa gömmesi gibi, kendini de battaniye ile bu kanepeye gömmüştür. Renklerin seçimi de açıklayıcıdır, konumları ise doğadaki gibi değildir: Kahverengi yeşili örtmektedir. Yeşil her ne kadar toprağa aitse de onun üstündedir doğada. Yeşil toprakta büyüyendir, bitkidir. Ama, aynı zamanda, Cirlot'un dediğine göre ölümdür. Kandinsky’ye göre "geçiş”tir. Yine Cirlot'un yazdığına göre tarlalardaki berekettir, doğanın rengidir. ${ }^{3}$

Battaniye gizemli bir sır saklayıcı, bir korunak gibidir. Halie'nin görmemesi gereken viski şişesini sakladığ 1 gibi çocuğu nereye gömdüğünü söylemeyen Dodge’u da saklar. Battaniye altına gizlenmek; dışarıdan gizlenmek, diğerlerinden gizlenmek, hatta kendinden gizlenmek demektir. Bradley takma bacağını çıkarıp uyuduğunda battaniye altına girmek ister. Çünkü çıkardığında korunmasızdı;; ne Shelly'nin ne de Dodge'un almasına izin verir. Oysa ki Dodge'un da gizlenmeye ihtiyacı vardır: Saçlarını tıraş ederek onu taciz eden Bradley’den de, yıllardır sakladığı gizden de. Kahverengi battaniye Dodge için adeta bir kabuk gibidir. Bachelard'a göre kabuk hem koruyucudur,

\footnotetext{
1 Aynı, s.57.

2 Aynı, s. 72

${ }^{3}$ Cirlot, "Colour"; A Dictıonary of Symbols, s.53. 
hem de mezar gibidir. ${ }^{1}$ Battaniye dış dünyanın acımasızlığına karşı koruyucudur ama aynı zamanda da altındakinin özgürlüğünü de kısıtlar. Dodge kendini dışarıdaki tehlikelerden korurken, aynı zamanda kendi kendini de mahkum etmiştir.

Gömülü Çocuk'ta oyun kişileri, dış güçlere, tehlikelere karşı savunmasızdır ve korunmak isterler. $\mathrm{Bu}$ nedenle de kendilerini güvende hissedecekleri bir şeylerin altına girerler. Dodge ve Bradley'nin battaniyenin altına girmesi gibi, yağmurdan korunmak için Bradley gazetenin, Vince ve Shelly de Vince'nin paltosunun altına girmişlerdir. Tilden, Shelly'nin kürkünü giydikten sonra çocuğun kaybolma öyküsünü anlatabilmiştir. Battaniyesini Bradley'e kaptıran Dodge bu kez Shelly'nin kürkünün altına gizlenmiştir. Örtmek, gizlemekle eşanlamlıdır. Halie, Peder Dawis'in görmemesi için Shelly’nin kürküyle, Bradley’nin takma bacağını gizler.

Kanepe, uzamı oluşturan tek oturma alanıdır. Ailenin tüm fertlerinin ortak paylaşım alanıdır. Ailenin tüm fertlerinin ortak paylaşım alanı olan bir salonda tek bir kanepenin olması, oturabilecek başka bir şeyin olmaması kanepeyi uzamın odak nesnesi haline getirir ve oyunun başlangıcında, olayların bu kanepe çevresinde geçeceğini imler.

Kanepe oyundaki dönüşümün de merkezinde durmaktadır. Dodge taşıdığı laneti ve bu paradokstaki statüsünü devredebileceği kişiyi; Vince'i bulduktan sonra ölür. Dodge öldükten sonra, laneti sürdürecek olan Vince bu kanepeye uzanır ve devir-teslimi tamamlanmış olur. Daha önce Tilden ve Bradley babalarının tahtını sallamışlar ancak ele geçirememişlerdir. Tilden uyuyan babasının üstünü mısır koçanlarıyla örtmüş, Bradley ise babası uyurken saçlarını kesmiştir. Tilden da Bradley de babaları gibi güçsüzdür, tahtı ele geçirecek denli güçleri yoktur. Vince toprağın kabuğunu çatlatan, kışı "öldürüp” gelen ilkbahar gibidir. Yağmur da sanki Vince'ın habercisi olmuştur. Halie'nin dışarısını cennete benzeten sözleri bir tesadüf değildir. Tilden'ın çocuğu gömülü olduğu topraktan çıkarması ve Halie'nin "kulesi”ne götürmesi de "karanlık mahzen” ile "duygusuz çatı katı"nın uzlaşması gibidir. ${ }^{2}$ Bu bir tür günah çıkartma edimidir de. Kanepenin yeni sahibi Vince mirası teslim almıştır. Laneti devredeceği yeni kuşak gelinceye kadar bu kanepeden ayrılmayacaktır. Kanepe eski çağlarda, erginleme törenlerinde ${ }^{3}$ kullanılan, ölüp-dirilmenin gerçekleştiği “sunak taşı"nı da çağrıştırmaktadır. Erginleme törenlerinde sunak taşının ritüel alanının ortasında durması gibi, kanepe de oyun uzamının tam ortasında durmaktadır. Bu törenlerde sunak taşına yatan kişinin öldüğü ve uyandığında da yeni biri olarak hayata başladığı düşünülürdü. Bu bağlamda Dodge’un ölümü lanetin yeni taşıyıcısı Vince'in “doğması” anlamına gelmektedir.

Krallık tahtının, varise devir-teslim törenidir oyunun sonunda yaşananlar. Vince ölen Dodge'un üzerine battaniyeyi örter ve gülleri göğsüne bırakır. Bu ölüm töreni yeni bir başlangıcın, yeni bir doğumun işaretidir. Bu doğum Vince'in doğumudur. Bottoms'a göre, toprağın bereketi ile

\footnotetext{
${ }^{1}$ Ön.ver. s. 136 .

2 Ayn1, s.47,53.

${ }^{3}$ George Thomson, Aiskhylos ve Atina, Çev.: Mehmet H.Doğan (İstanbul: Payel Yayınevi, 1990), s.123.
} 
ailedeki erkek şiddeti Vince ile uyanmıştır. ${ }^{1}$ diğer bir deyişle, R.Gilman'ın işaret ettiği gibi "sevgisizlik" yerini sevgiye bırakmayacaktır. ${ }^{2}$

Oyunda uzamı belirleyen bir diğer nesne de televizyondur. Televizyon oyunun başlangıcında 1şık kaynağı olarak da kullanılır ve mavi 1şı̆̆ıyla karanlıkta kanepede oturan Dodge’u aydınlatır. Soğuk, mavi ışık Dodge'un yüzüne düşürülerek onun çürümüşlüğü, uzamın soğukluğu vurgulanırken, aynı zamanda gizemin kaynağı olan ve cinayeti işleyen Dodge üzerine de yoğunlaşmış olur. Dodge oyun başlangıcında ilk görülendir ve televizyon ışığı da bunu vurgular.

Televizyonun bir diğer anlamı da Amerikan Rüyasının bir parçası, bireylere sunulan ve onları birbirlerine karşı yabancılaştırıp, yalnızlaştıran bir meta oluşudur. Oyunda teknolojinin "nimeti"nin, parçalanmanın, bireylerin kendi dünyalarına kaçışının simgesidir. Dodge bilinçaltını sürekli kurcalayan, onu rahatsız eden geçmişinden, günahlarından, ailesinden ve sonunda kendinden kaçıp televizyona sığınır. Çocuğu arka bahçeye gömdüğü gibi kendini de o televizyonla birlikte kanepeye gömmüştür. Kendine ayrı bir yaşam alanı yaratmıştır. Dodge televizyonda Amerikan futbolu izler ve onu sahiplenir. Yapacağı başka bir şeyi yoktur ve ondan uzaklaşması imkansızdır. Sistem, istediği psikolojik ve biçimsel parçalanmayı her eve televizyon girmesini dayatmakla ve bireylere asla ulaşamayacakları "sanal dünyayı" sunmakla başarmıştır. Televizyon galiptir, Dodge ise kurban...

Televizyondan ses de gelmez. Çünkü ne söylendiği çok da önemli değildir. Bu durum, bir iletişim aracı olan televizyonun, iletişimi imkansızlaştırdığını, seyredenleri kendi dünyalarına hapsettiğini ve tekilleştirdiğini göstermektedir. Bu iletişim aracının, aralarında hiçbir iletişim olmayan, yalnız insanların uzamında bulunması bir karşıtlık durumu da yaratmaktadır. Sistemin kurucu öğesi ve devamlılığını sürdüren meta olarak baktığımızda, kapitalizmin temsilcisi olarak algılanabilir. Yaşananların suç ortağıdır televizyon. Onun ışığıyla (mavi 1şık) aydınlanan ev sürekli geceyi yaşar. Üstelik Baudrillard'ın işaret ettiği gibi televizyondan artık göstergeler değil görünümler alınmaktadır; anlık bir savaş görüntüsü ile bir deterjan reklamının birbirinden farkları yoktur ve gerçekte de hiçbir anlama karşılık gelmemektedirler. "Sistemin yerli yerinde olduğunu kanıtlama arzusundan başka bir işe yarayamamaktadırlar."3

Dodge'un kanepe ve televizyon ile sınırlanmış dar uzamını tamamlayan diğer nesneler de sarı gölgeli ışık veren bir lamba ve üzerinde küçük ilaç şişeleri olan bir sehpadır. Dodge adeta bir keşiş kulübesindedir; yalnızlığı içinde "barınma ediminin mutlak biçimi”ni yaşamaktadır.

Dodge hastadır ve sürekli öksürmektedir. Halie'nin ısrarlarına, kontrolüne rağmen ilaçlarını içmez. Dodge'un bu hastalıklı durumu ve ilaçlarını içmemesi ölüme yakın olduğunu imlemektedir. Dodge bir kez ilacını içer. O da Tilden'ın arka bahçeye gitmek istediğini söylediğinde. Evdekiler bir

\footnotetext{
1 Ön.ver. s. 180 .

${ }^{2}$ Richard Gilman. "Introduction”; Sam Shepard: Seven Plays (New York: Bantam Books Inc, 1981), s.xxv.

${ }^{3}$ Oğuz Adanır. Baudrillard'ın Simülasyon Kuramı Üzerine Notlar ve Söyleşiler (İzmir: Dokuz Eylül Yayınları, 2000), s.43.

${ }^{4}$ Bachelard, Mekanın Poetikası, s.59.
} 
sır perdesi altında yaşamaktadır. $\mathrm{Bu}$ sır onların ne birlikte olmalarına izin verir, ne de ayrı yaşamalarına. Tilden'ın gitmek istemesiyle krize girer Dodge.

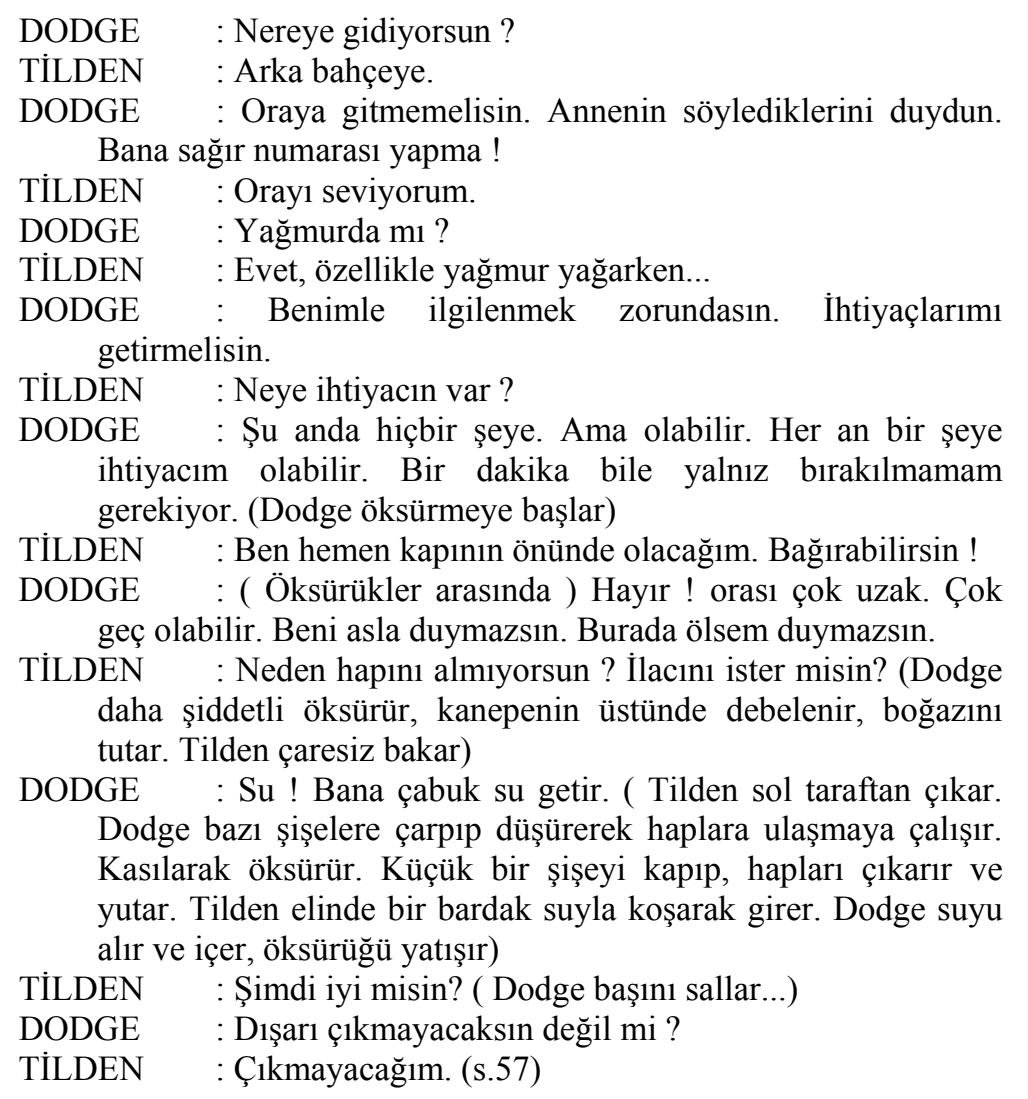

Dodge'un bu krizi yalnız kalamama korkusuyla açıklanabileceği gibi, bahçede yatan ve evin içini de saran gizle de ilgilidir. Tilden'ın her arka bahçeye çıkışı Dodge'a bu gizi hatırlatır. Tilden'ın gitmesine engel olur, kriz de geçer. Bu bağlamda ilaç kutuları, yalnızlığı, korkuları, evin her yanını saran gizi ve uzama hakim olan hastalıklı durumun altını çizmektedir.

Lamba, kanepenin hemen yanında bulunmasıyla ve aydınlattığı alanla Dodge'un uzamının sınırlarını belirler. Ev karanlıktır. Lamba da "sarı, gölgeli" ışığıyla evdeki gizemin tamamlayıcısıdır. Ve Dodge'u aydınlattığı dar uzama hapseder. Aynı zamanda, Bachelard'ın sözleriyle bağdaştırırsak lamba “evin gözüdür." Vince’1 "bekleyen"dir. ${ }^{1}$

Merdiven, salon ve yatak odasını birbirine bağlar. Verandanın iç ve dış uzamı birbirinden ayırması ya da bağlaması gibi, merdiven de alt kat ve üst katı birbirine bağlar. Dar uzamlarına kendilerini hapsetmiş bireylerin kopukluğunu, aralarındaki mesafeyi, yalnızlığını, iletişimsizliklerini gösterir. Merdivenden yukarı çıkmak "güç”ü gösteren bir eylemdir. Başlangıçta, uzama, aileye uyum sağlayamayan Shelly, yukarı çıkıp indiğinde daha kararlı ve cesurdur. Bu durum Bradley'in takma bacağını alması ve vermemek için direnmesinde de görülür.

\footnotetext{
${ }^{1}$ Ayn1, s.63. 
Oyunun başlangıcında salonda bulunan Dodge ve yatak odasında bulunan Halie birbirlerini görmeden uzun bir süre konuşurlar. (metinde 10 sayfa boyunca) Sürekli merdiven yukarısına bakan Dodge ürkektir, tedirgindir. Halie'nin, viski içtiğini görmesini istemez. Merdivenin ötesi görünmez. Bir bilinmeyenden, bir giz perdesinin ardından geliyor gibidir Halie'nin sesi. Bu durum bireylerin uzamlarını kesin sınırlarla ayırdığını gösterdiği gibi, evdeki gizemle, saklanan sırla da örtüşmektedir. Halie, Peder Dewis ile görüşmek için dışarı çıkmadan önce üst kattan (kendi uzamından) aşağı inerken sanki başka bir dünyadan geliyor gibidir. Öyle bir yanılsama içindedir ki salonda oturan Dodge ve Tilden' 1 fark etmez bile.

$\mathrm{Bu}$ evde yaşayanlar her ne kadar uzamlarının sınırlarını kesin çizgilerle belirlemiş olsalar da, kendi yanılsamaları içinde "gerçek"i görmeseler de, arka bahçenin gerçeğini yok saysalar da dış uzam aslında tamamen evin içindedir: Tilden arka bahçenin ürünlerini sürekli eve taşımaktadır. Bunları iç uzamda, dış uzama ait olan kova ve süt sağma taburesinde temizlemektedir. Tilden bahçenin ürünlerini eve getirirken arka bahçenin çamurunu da içeri taşımaktadır. Dışarıda, birinci ve ikinci perde boyunca yağmur yağar. Yağmur suları da içeri taşınır. Birinci perdede Tilden ve Bradley ile, ikinci perdede Vince ve Shelly ile. Hepsi de iç uzama girdiklerinde sırılsıklamdır. Dışarının yağmuru içeriyi de sslatır.

Oyunun sonunda Tilden, "gömülü çocuk"u, arka bahçeden, topraktan çıkarmış, dizlerine kadar çamura bulanmış, kolları ve elleri çamur içinde, çamurlu kumaş parçasına sarılmış çocuk cesedini merdivenden üst kata çıkarken, dış uzam artık tamamen içeri girmiş, iç uzama hakim olmuştur. Dodge ölmüş, çocuk topraktan çıkmış, Vince laneti devralmıştır. Artık dışarısı içeri, içerisi de dışarısıdır.

Ceset topraktan çıkar, Dodge ölür. Tilden cesedi üst kata çıkarır, Halie bahçedeki ürünleri görür.

Uzam yer değiştirmiştir artık.

Dış uzam (arka bahçe) toprağın altı ve toprağın üstü olarak, iç uzam da; alt kat ve üst kat olarak ayrılmıştır. Toprağın altında çocuk cesedi, üstünde Tilden, evin alt katında Dodge, üst katında Halie vardır. Bu bağlamda dış uzam ve iç uzam arsında koşutluk vardır. Günahı, suçu işleyenler üstte, ölenler alttadır.

Evin içindeki nesnelerin renklerinin seçiminde de arka bahçeye ve toprağa ait renkler kullanılmış, dış uzam içeri taşınmıştır: " koyu yeşil bir kanepe", "tahta bir merdiven", "kahverengi bir televizyon", "kahverengi battaniye", "tahta döşemeli bir veranda".

Koyu yeşil kanepesinde, kahverengi battaniye altında bir ceset gibi yatan Dodge'un kostümü de bu düşünceyi destekler görünmektedir: "haki renkli iş pantolonu”, "kahverengi terlikler".

Shepard, uzamı betimlerken canlı bir renk kullanmamış, "yıpranmış", "soluk", "eskimiş", "gölgeli”, "karanlık” gibi sözcüklerle tanımlamıştır. Bu seçim evdeki lanetin y1llardır sürdüğünü 
gösterdiği gibi, arka bahçedeki gizin, karanlığın eve yansımasını da sağlamaktadır. Dışarısı da tekin değildir ve ürküntü verir, içerisi de. Dışarının yağmurlu, puslu havası içeriyi de kaplamıştır. Yıpranmış kumaşlar, halı ve döşemeler, iyice eskimiş elbiseler, renklerin karanlı̆̆ 1 , içerideki gizemi, yoksunluğu daha da arttırmaktadır.

Vince'in saksofon kutusu, bu uzama uymayan, yakışmayan bir nesne olarak durur oyun boyunca. Vince eve geldiğinde neşeli, canlı, hayat dolu biridir. Bu haliyle aileye girmesi mümkün değildir. $\mathrm{O}$, dönüştükten, şiddete yöneldikten, onlar gibi davranmaya başladıktan sonra kabul edilir aralarına. Biliyoruz ki artık Vince o saksofonu çalmayacaktır. Dodge evi Vince'e bırakmıștır. Bu, laneti de bırakmak demektir. Lanet, yeni kuşak Vince ile devam edecektir. Uzam her seferinde temizlense de, o evden kırık içki şişeleri, mısır kabukları, çamur eksik olmayacak, zaman içinde her şey daha da yıpranacak, ev çöplük olmaktan kurtulamayacaktır. 

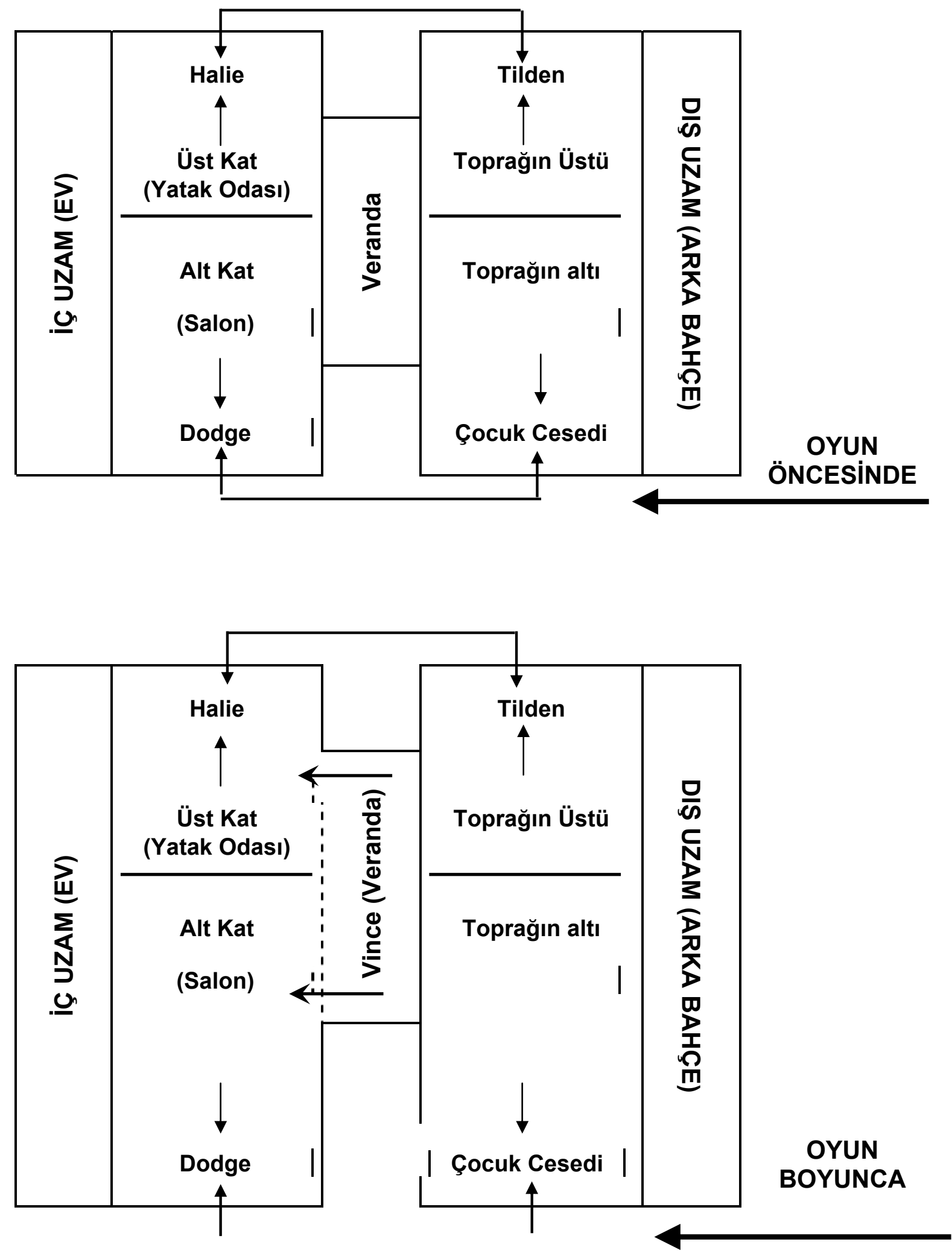
Gömülü Çocuk'un zaman boyutu, uzam boyutunda olduğu gibi, karakterlerin dönüşümü, eylemlerin yönelimi ve oyunun iletisi ile bir eşyapılılık ilişkisi içindedir.

Birinci perdede zaman; gündüzdür.. dışarısı yağmurlu ve karanlıktır. Gündüz olmasına karşın içerisi de karanlıktır. Kanepenin yanında duran "sarı gölgeli 1şık veren lamba” içerinin karanlığını gidermez. Gündüz de olsa onlar içeride hep geceyi yaşamaktadırlar.

İkinci perdede zaman; gecedir. Dışarıda yağmur yağıyordur. Yağmurun hala yağıyor olması gizin süreğenliğini anlatmaktadır. İçerideki karanlı̆̆g, gecenin karanlığı daha da arttırmıştır. Gece, tüm sırları ve evde işlenen günahı örter. Suç da muhtemelen bir gece işlenmiştir. Bunun için de kendi uzamlarında hep geceyi yaşamaktadırlar. Laneti devralacak Vince de gecenin bir yarısı çıkagelir. Giz, ilk kez konuşulmaya, sorgulanmaya başlanır. Gece, Vince'in kaybolduğu, sırrın daha keskinleştiği, ortaya çıktığı zaman dilimidir. Sır, gece açıklanır. Gece, Cirlot'un yazdığına göre karanlık ve ölümün simgesi olmasının yanı sıra, yaradılıştan bir önceki zamandır. Gece, gündüzün, bereketin habercisidir, günışı̆̆ının müjdecisidir.

Üçüncü perdede zaman, sabahtır. Yağmur dinmiş, güneş açmıştır. Sırrın açığa çıkmasıyla beraber aile bu günahla yüzleşmiştir. Adeta, Žižek'in dediği gibi “yalan alanı içinde 'bastırılmış’ hakikat" ortaya çıkma "zorunluluk”u ile karşı karşıya kalmıştır. ${ }^{1}$ Sabah, yağmurun dinmesi ve "parlak güneş" yeni bir başlangıcı imliyor. Bu durum, -lanet Vince ile sürecek de olsa- yine de umuda bir pencere açmaktadır.

\begin{tabular}{|c|c|c|c|}
\hline & 1. PERDE & 2. PERDE & 3. PERDE \\
\hline 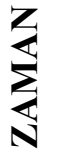 & GÜNDÜZ & GECE & GÜNDÜZ \\
\hline 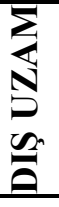 & $\begin{array}{c}\text { YAĞMUR YAĞIYYOR } \\
\text { (KARANLIK) }\end{array}$ & $\begin{array}{c}\text { YAĞMUR YAĞIYOR } \\
\text { (KARANLIK) }\end{array}$ & $\begin{array}{c}\text { YAĞMUR DİNMIŞ } \\
\text { ("PARLAK GÜNEŞ") }\end{array}$ \\
\hline 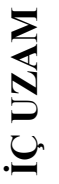 & KARANLIK & KARANLIK & AYDINLIK \\
\hline
\end{tabular}

\footnotetext{
${ }^{1}$ Bülent Somay ve Tuncay Birkan (Hazırlayan), "Sibermekan ya da Varolmanın Dayanılmaz Kapanımı"; Kırılgan Temas; Slavoj Žižek'ten Seçme Yazılar . Çev.: Tuncay Birkan (İstanbul: Metis Yayınları, 2002), s.163.
} 
Yazarın "uzam” ve "zaman" kullanımı, karakterlerin dönüşümü ve değişimi, oyunun iletisi ile koşut olarak ilerlemektedir. Oyun kişileri yaratılan uzamın bir parçasıdır ve uzam o kişilerle birlikte soluk alıp verir. "uzam" ve "zaman" bir oyun kişisi gibidir ve bunun bir "dil" olarak kullanmak Shepard'ın ustalığıdır.

\section{KAYNAKÇA}

Adanır, Oğuz. Baudrillard'ın Simülasyon Kuramı Üzerine Notlar ve Söyleșiler. İzmir: Dokuz Eylül Yayınları, 2000.

Bachelard, Gaston. Mekanın Poetikası. Çev: Aykut Derman. İstanbul: Kesit Yayıncılık, 1996.

Bottoms, Stephen J.. "Strychnine in the Gut; Curse of the Starving Class (1977) and Buried Child (1978);

The Theatre of Sam Shepard; States of Crisis. New York: Cambridge University Press, 1998.

Cirlot, J.E. A Dictıonary of Symbols. London: Routledge \& Kegan Paul, 1983

Gilman, Richard. "Introduction”; Sam Shepard: Seven Plays. New York: Bantam Books Inc., 1981.

Marranca, Bonnie. Amerikan Dreams; The Imagination of Sam Shepard. New York: PAJ Publications, 1981.

Maranca, Bonnie and Gautam Dasgupta. "Sam Shepard"; American Playwrights; A Critical Survey. New

York: Drama Books Specialists (Publishers), S: 81-113.

Morley, David ve Kevin Robins. Kimlik Mekanları. Çev:Emrehan Zeybekoğlu. İstanbul: Ayrıntı Yayınları, 1997.

Sam Shepard. Toplu Oyunları 1: Gömülü Çocuk. Çev: Şükran Yücel; Vahşi Batı. Çev: Yıldırım Türker;Aç Sınıfın Laneti. Çev.: Pınar Kür. Ankara: Dost Kitabevi Yayınları, 2000.

Shewey, Don. Sam Shepard. New York: De Capo Press, 1997.

Somay, Bülent ve Tuncay Birkan (Hazırlayan). "Sibermekan ya da Varolmanın Dayanılmaz Kapanımı";

Kırılgan Temas; Slavoj Žižek'ten Seçme Yazılar. Çev.: Tuncay Birkan.İstanbul: Metis Yayınları, 2002. Thomson, George. Aiskhylos ve Atina. Çev.: Mehmet H.Doğan. İstanbul: Payel Yayınevi, 1990.

Urry, John. Mekanları Tüketmek. Çev: Rahmi G. Öğdül. İstanbul: Ayrıntı Yayınları, 1999. 